\title{
Financial Impediments to Road Infrastructure Development in India
}

\author{
Gunturu Sai Avinash, Jaskiran Arora
}

\begin{abstract}
India is the fastest developing economy as indicated by Central Statistics Organization (CSO) and International Monetary Fund (IMF), with “Gross Domestic Product (GDP) growth averaging 7.5 percent between 2014-15 and 2016-17” (Economic Survey 2017-2018, 2018) respectively. And, Investment in infrastructure drives GDP of a country and forms its lifeline. Investment in infrastructure establishes long haul development by propelling production and transportation of the material to the production sites and markets, more employment opportunities and safety for the citizens etc. However short-term political cycles and investment horizons, an absence of feasible financial infrastructure, unseemly tactless, unrefined risk assessment framework and an absence of long-term view; prompts various obstacles to infrastructure growth and development in a country.

Infrastructure sector in India is facing major financial issues leading to shortage of investable funds in the vital sector. The companies are confronting huge cost over-run and schedule overrun because of a variety of regulatory hindrances leading them to search for approaches to deal with their financial reporting and provisioning judiciously while meeting fundamental, basic needs in infrastructure. These likewise deflect the private investors to invest in infrastructure ventures.

This paper presents the trends in investment, highlighting the relative investment made by Government, Public Private Partnership (PPP) and other models. It further examines the operational and financial hindrances faced in road projects and suggests that by overcoming certain administrative deterrents long-term investors can be attracted to invest in an asset class that produces stable returns over the long haul and dependably gives imperative answers for public needs and significant value for money.

This paper proposes that there is a need to quit considering infrastructure only as a fiscal stimulant, but to start thinking of it as a viable and sustainable investment opportunity
\end{abstract}

Keywords - Impediments; Financing Infrastructure; Roads, Investments; Public Private Partnerships; Regulatory hurdles; Operational hurdles; Funding opportunities; Investment opportunities.

\section{INTRODUCTION}

Infrastructure is the foundation of a country a crucial role in any financial system. An efficient and higher quality infrastructure not only does promote the movement of people, goods - an essential element of the supply side of the economy-but also delivers economic incentives to public as well as private sector participants.

Infrastructure investments are sought by large as well as small economies, as it enhances and support growth in the long term via multiplier effects. Investment in infrastructure drives Gross Domestic Product (GDP) of a country and forms its lifeline.

Infrastructure establishes for long haul development by propelling production and transportation of the material to the production sites and markets, more employment opportunities and safety for the citizens.

Financing levels miss the mark concerning the future infrastructure investment expectations, and without government budget allotments. To efficiently and adequately connect with the private sector, support is necessary to these plans. Public-Private Partnerships (PPPs) have been distinguished as the most appropriate mode for the execution of projects - and for sure, are quickly turned into the financing norm.

Besides these frameworks infrastructure sector is still facing major financial issues leading to shortage of investable funds. The concessionaires are confronting huge cost over-run and schedule overrun because of a variety of regulatory hindrances leading them to search for approaches to deal with their financial reporting and provisioning judiciously while meeting fundamental, basic needs in infrastructure. These likewise redirect private investors to invest in infrastructure ventures. Thus, the risks, including uncertainty, assume more prominent centrality for banks and concessionaire. Besides the usual project risks, infrastructure projects have other risks because of the interface with regulators and government organizations.

\subsection{Infrastructure Investment Slowdown}

Infrastructure development projects are a capitalconcentrated with immense initial costs and low operating expense. It requires long haul finance as the development time period for such endeavours are frequently longer, banks who finance the infrastructure development projects can only be repaid from the incomes created by the undertaking. Yet, high transactions expense arising from deficient and inefficient infrastructure prevents the economy from realizing its full growth potential regardless of the progress on other fronts.

\footnotetext{
Revised Manuscript Received on September 10, 2019.

Gunturu Sai Avinash, BML Munjal University, National Highway 8, 67 KM Milestone, Gurgaon, Haryana 122413, India.

(E-mail: saiavinashgunturu@gmail.com)

Dr Jaskiran Arora, BML Munjal University, National Highway 8, 67 KM Milestone, Gurgaon, Haryana 122413, India.

(E-mail: jaskiran.arora@bmu.edu.in)
} 


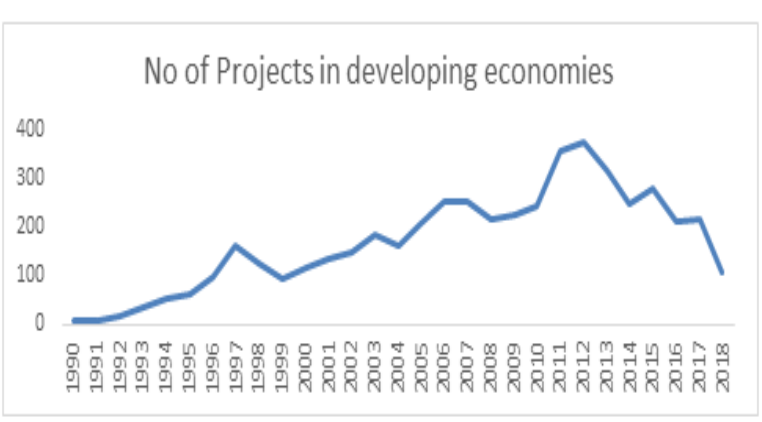

[Source: World Bank]

Private finance has a valuable role to play in meeting infrastructure requirements of a developing economy. Banks and institutions provide the upfront capital investment to build the projects an economy needs but require predictable revenue streams to support this financing. Securing the finance is essential if the economy is to renew its ageing network utilities, remain internationally competitive and boost growth. Yet several financing challenges have emerged post-crisis.

\section{Total Investment in Million \$ Developing Countries)}

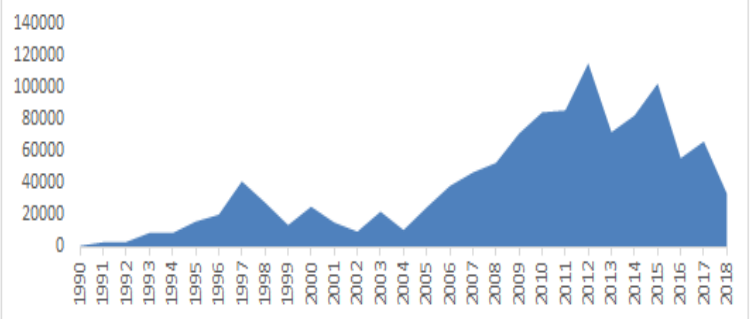

[Source: World Bank]

The rapid decline of private investment in infrastructure over the past few years has been relatively largely because due to a growing concentration of risks in banks in terms of sector exposure and asset-liability maturity mismatch.

Broad improvement of the infrastructure sector, along with restorative measure, can unswervingly drive and sustain the growth of a developing economy. A cautious analysis of the variables involved in the infrastructure sector, which have relieved development is required before taking the appropriate remedial measures.

India's infrastructure facilities, including transport, sanitation and electricity, are still estimated to be inadequate for its immense population-17.99 percent of the world's population resides here. Infrastructural inadequacies present a crucial challenge for sustainable economic growth in a number of infrastructure sectors, especially road infrastructure, a sector in which the nation lags behind (India Brand Equity Foundation, 2018).

\subsection{Indian Road Infrastructure}

The significance of road infrastructure in a developing economy can't be overemphasized. It forms the lifeline of an economy and gives it the fundamental support network to substitute parts of the economy by broadening limits everywhere. A well-developed physical availability as a rail system or road network, for instance, can encourage the producers and consumers by encouraging faster delivery of horticulture, encourage education by empowering students to get educational opportunities that are not generally of lack of commercial bank funding. The decline resulted

effortlessly accessible, guaranteed well-being of the citizens by speedily achieving the destitute to the medicinal services , guarantee country's safety and security by empowering the movement of military, and generate more noteworthy work openings.

The burgeoning travel needs of the passengers and the transportation prerequisites of the regularly expanding and prospering of businesses calls for better and improved road infrastructure in the nation. It has a multiplier impact on improvement and progression in the nation and hence requests conspicuous thought of the policymakers.

While the business should outfit to pull in players from various divisions to deal with the demand yet existing infrastructure firms are expanding their business points of interest into other, more lucrative segments. Time and cost overruns much above the original estimates point to limit capacity and poor usage of the current ability to deliver work on time and moreover adding to the stressed balance sheet of privately-owned businesses.

As of June 2018, with 5.4-million-kilometre network of roadways, India ranks second worldwide, transporting 85 percent of the total passengers travelling in the country and more than 60 per cent of all the goods in the country. Amongst all the infrastructure projects in India, the growth in this sector has been the highest. Construction of highways reached 122,432 km during 2017-2018 with an average of $28 \mathrm{~km}$ of road built each day. Government has also been taking many initiatives to boost the investment in roads like increasing the revenue allocation for the cause, launching infrastructure mutual funds, getting funding from World Bank etc. to provide a further impetus to the road infrastructure in the country; and proposing to implement 'Value Engineering Programs' to enhance the use of new technology and material in the highway projects executed in the country. Government is also taking series of initiatives to attract interested investors in the sector, with an aspiration to double the length of the highways to 200,000 km by 2022 (India Brand Equity Foundation, 2018).

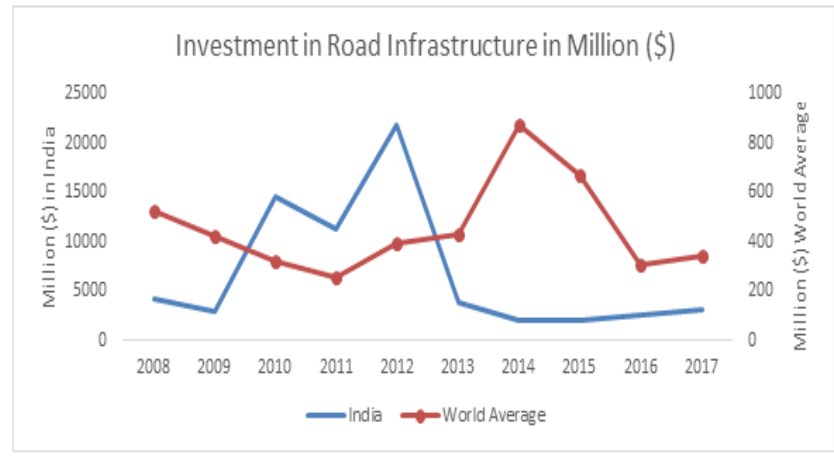

[Source: World Bank]

"Until the mid-2000s, there was no major demand from the financial system to finance road infrastructure investment as it was low and financed to a great extent by budgetary allocations" (Planning Commision Government of India). The financial framework had the option to react to the quickly rising demand for credit by organizations involved in road infrastructure to a great extent since banks

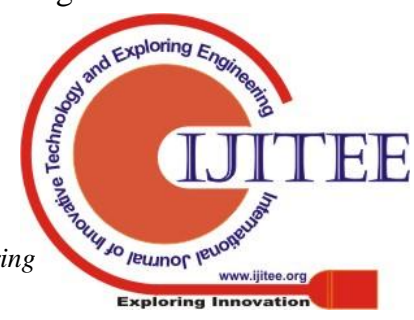


ventured up loaning. Subsequently, it is assessed that banks had the option to provide about a large portion of the debt obligation needs infrastructure investment.

"This quick growth in bank credit to infrastructure has brought about a more prominent and greater concentration of risks in banks, due to ALM mismatch" (Planning Commision Government of India). The road sector is confronting noteworthy requirements as the exposure is as of now high. It might be advantageous to call attention to point out the funding gap.

The growth and support considering the recent trends is worrisome. Recently the total investment in road infrastructure in India as compared to World average exhibits a very retarded growth, with the world averages being a way higher than the investment in road infrastructure in India. In the ongoing past, it tends to be seen that the investments in road infrastructure in India have altogether dropped.

One of the standard clarifications behind the private underinvestment in the road infrastructure is that the investors in road infrastructure make significantly littler advantages than those busy with development in land, real estate, and industrial sectors. These dainty margins are on a very basic level because of the delays in generally venture execution, investment atmosphere bottlenecks, and unhealthy rivalry. Players from various segments find the road infrastructure territory to be less appealing as a result of its lower net incomes, the executives by the pervasively feeble open organization, challenging project logistics, and contract administration arrangements.

"Over the life of a PPP contract unexpected occasions and possibilities, that couldn't have been anticipated when the agreement was marked, will emerge. It is likely that the parties will get into a disagreement regarding how the agreement ought to be deciphered, or whether the two parties have been executing as concurred. Now and again, these questions may result in the early termination of the agreement, aside from the dangers of the agreement related disputes, renegotiation, and conceivable termination" (Srivastava, 2013).

\section{RESEARCH METHODOLOGY}

In the recent past, it can be observed that the investments in road infrastructure have drastically dropped. Bottlenecks to development of road infrastructure are caused by many reasons. This vulnerability influences the risk appetite of investors and lenders to invest in infrastructure. The issues impinging on road infrastructure framework development include both money related and non-budgetary variables. While financing remains a main consideration for all development projects, the non-financial issues assume equal weightage and get proper consideration. Road infrastructure sector is confronting significant constraints and prerequisites. It may be beneficial to call attention and point out the funding gap.

\subsection{Analysis}

Designed an Indian Equity Infrastructure Portfolio to investigate the performance of companies in the Indian infrastructure industry (FactSet Industry Classification) with minimum market capitalization of $\$ 100$ million, 6-month average daily turnover greater than or equal to $\$ 3$. Top 30 companies by market capitalization formed the final portfolio. Where there is a security cap of 3 securities for each industry. If in case more than three companies qualified for inclusion from one industry, all additional securities (starting from the fourth largest) in that industry are replaced by the next largest securities from the selection list, that belong to non-capped industries. The portfolio was weighted based on their security-level free float market capitalization. A single security cap of $4.90 \%$ is applied. The portfolio was back tested for 3 years. YTD (Year to Date) return and volatility of the portfolio has been investigated. This analysis provided the opportunity and need for the improvement of bond market to raise money and fund future infrastructure projects.

Number of infrastructure projects and private investment in infrastructure in developing economies for the past 20 years were investigated to examine the trends and reasons for the slow down for the investment.

Analyzed the NHAI construction activity to gain exposure to the reasons leading to the slow construction rate which had a correlation with regulatory hurdles impacting financials of the concessionaire. Also analyzed the Hybrid Annuity Model (HAM) model and its impact on the road infrastructure sector, trend of HAM projects awarded by NHAI in the past 3 years and also considered the percentage of Hybrid Annuity Model (HAM) model project awaiting Financial Closure (FC) to total Bid Project Cost (BPC) of publicly listed concessionaires namely Dilip Buildcon, Sadhav Infra, PNC Infra, Ashoka Buildcon, MEP Infra, Welspun, KNR construction and IRB Infra which have a high level exposure to the HAM projects in their project portfolio.

\subsection{Interviews}

Individual, group and expert- were the primary means for the case study analysis addressing the hurdles faced by a public infrastructure company during the execution of Raipur Bilaspur Highway Project, Six Lane Gundugolanu to Rajahmundry Road Project, Narnaul Bhiwani 4 Lane Road Project, and Patiala Bathinda 4 Lane Road Project which were terminated resulting in irreversible loses for the concessionaire and directly impacting the financials of the publicly listed company.

The case study analysis provided the opportunity to trace the impediments to the growth of road infrastructure sector in India due to several regulatory hurdles and lack of countries adherence to the regulatory practices at the procurement stage of Public Private Partnership (PPP) project and the reasons for declining private participation in infrastructure sector by lenders and infrastructure companies.

4. Case Analysis for Project Impediments to Infrastructure Growth in India

To understand the impediments to road infrastructure projects in India, a case study for four projects that were terminated, was conducted. 
Case Study 1: Termination of Raipur Bilaspur Highway Project:

"6 Laning of Raipur Bilaspur section of NH 200 in the state of Chhattisgarh to be executed BOT (build operate transfer) on Design Build Finance Operate Transfer (DBFOT) pattern under NHDP phase 4 was awarded to IVRCL Raipur Bilaspur Toll ways Limited with a concession period of 25 years and tolling KM's of 125.525 " (NHAI).The total project cost as per the authority estimates was INR $1216 \mathrm{cr}$ with a premium of INR $45.45 \mathrm{cr}$ payable from COD.

The obligations faced by IVRCL Raipur Bilaspur Toll ways Limited due to regulatory hurdles were, the authority was not able to provide $80 \%$ of Right of Way (ROW) within 180 days and $100 \%$ of ROW 90days thereafter the execution of concession agreement. Added, they were not able to provide Forest clearance, MoEF (Ministry of Environment and Forest) clearance within scheduled timelines, couldn't complete the estimates of utility shifting, and couldn't obtain approval of Rail over Bridge (ROB) up to General Arrangement Drawing (GAD) within timelines.

Though a lot of obligations faced by the concessionaire were fulfilled after awarding the project which includes acquiring position of stone quarry, applied permission for extraction of boulders and established their hot mix plant, crusher and other equipment. The concessionaire has also appointed design consultant and completed majority of drawing and submitted it for approval. Other obligation of concessionaire which was fulfilled was they have completed Technical, Traffic Appraisal Report, and Appointed Syndicating Agency for tying up of financial support, obtained In Principal sanctions to cover Debt component from lenders with validity period.

This project was later terminated due to a delay in financial closure, NHAI encashed Performance Bank Guarantee (PBG) equivalent to Earnest Money deposit (EMD) of 12.16 crore. The prime reason for the termination of the projects was due non-fulfilment of Authority obligation of providing $100 \%$ of Right of way (ROW) before the financial closure, lenders could not extend the validity, there by concessionaire couldn't complete the financial closure.

Case Study 2: Termination of Six Lane Gundugolanu to Rajahmundry Road Project

"6 Laning of Gundugolanu Rajahmundry Section of NH 5 in the state of Andhra Pradesh to be executed as BOT (toll) on DBFOT pattern under NHDPA Phase 5 was awarded to IVRCL Gundugolanu Rajahmundry Toll ways Limited with Total project cost of INR 1617 Cr" (NHAI). Concession period for this project was 24 years from the appointed date with tolling Km's of 120.741 .

In this project the fulfilment of obligations by the concessionaire involves acquiring position of stone quarry, application of permission for extraction of boulders and establishment of hot mix plant, appointing design consultant and completing most drawings and ready for submission for authority approval. Concessionaire has also submitted sketches demarking encumbrance like irrigational Canal, Drain, Railway Line, Utility Lines etc and requested NHAI for early clearance. The concessionaire has also completed technical traffic appraisal report, appointed syndicating
Agency for tying up of financial support, submitted documents for sanctions of debt component from lenders.

Even after the fulfilment of all the obligations of concessionaire after awarding the project the concessionaire still faced a lot of regulatory hurdles like presence of perennial irrigation canal all along the stretch within ROW for length of $35 \mathrm{Km}$ which is in existence since 105 years used for irrigations of adjoining areas, presence of drain of length of over $20 \mathrm{Km}$ within ROW, Presence of Railway Line which runs parallel to project corridor with in Row for $5 \mathrm{~km}$ length. All the above obstructions were meant to be relocated before taking up implementation of the current scope. Authority neither envisaged these issues, nor estimated the expenditure, timelines required. These issues were beyond the scope of the concessionaire and NHAI must provide funds. Even though the concessionaire provided all the required technical drawing and estimates, NHAI hasn't taken any decision.

The cumulative length affected due to these issues was about $60 \%$ of the total Length. The authority was not able to provide $80 \%$ of the ROW up to GAD level within the timelines which happens to be the pre-requisite for financial sanctions by the lenders.

As a result, Termination of the project took place due to Non-submission of PBG and delay in financial closure, NHAI encashed EMD of Rs 16.17 Cr. In response, IVRCL Gundugolanu Rajahmundry Toll ways Limited (IGRTL) filed a writ petition in the Honourable High Court, Hyderabad for Illegal Termination and encashment of EMD.

Case Study 3: Termination of Narnaul Bhiwani 4 Lane Road Project

"4 Laning of the Rai Malikpur (Rajasthan Border)Namaul-Mahendragarh-Dadri-Bhiwani-Kharak corridor in the state of Haryana executed as BOT (toll) on DBFOT pattern (Haryana Government) was awarded to IVRCL Narnaul Bhiwani Toll ways Limited (State Highway) with a total project cost (TPC) of INR 1200CR" (NHAI).The concession period was 20 years from the appointed date with a premium $2 \%$ of the realisable revenue from the COD. The total tolling KM's of the state highway were 151 KM's.

In this project the fulfilment of obligations by the concessionaire involves acquiring position of stone quarry in Rajasthan with longer leads with additional expenditure and submitted compensation request because of that, application of permission for extraction of boulders and establishment of hot mix plant, appointing SHELADIA ASSOCIATES as design consultant and completing most drawings and ready for submission for authority approval. The concessionaire has also completed technical traffic appraisal report, appointed syndicating Agency for tying up of financial support, submitted documents for sanctions of debt component from lenders.

Though after fulfilment of concessionaire obligations after "the project of 4 Laning of the Rai Malikpur (Rajasthan Border)-Namaul-Mahendragarh-Dadri-BhiwaniKharak corridor in the state of Haryana by IVRCL Narnaul Bhiwani Toll ways Limited" (Haryana Government), the

Published By: 
concessionaire still faced a major regulatory obstacle apart from being provided with $80 \%$ of ROW within 180 days and $100 \%$ of ROW 90 days thereafter the date of execution concession agreement, provide forest clearance by MoEF within scheduled timelines was that a ban was imposed on mining by Haryana State Government for extraction of stone aggregates and the authorities couldn't provide the concessionaire for arranging dedicated stone quarry.

These factors finally resulted in the non-submission of PBG and delay in Financial Closure, PWD, Haryana encashed EMD of Rs.24.00Cr.

Case Study 4 : Termination of Patiala Bathinda 4 Lane Road Project

" 4 Laning of the Patiala -Sangrur-Bathinda section of NH-64 in the state of Punjab to be executed as BOT (toll) on DBFOT pattern was awarded to IVRCL Patiala Bathinda Toll ways Limited with a total Project Cost (TPC) of INR 1586 Cr" (NHAI). Concession period was 24 years from the appointed date with tolling KM's of 166.450 .

The obligations fulfilled by the concessionaire after the project being awarded were tie ups with existing permission holders for supply of crushed aggregates, existing holders for extraction of boulders, Identified suitable land for establishment of hot mix plant. The Concessionaire has also appointed design consultant and completed majority of drawings which were ready for submission for authority approvals. They have also completed technical, traffic appraisal report, appointed syndicating agency for tying up of financial support and submitted documents for financial sanctions of debt component from the lenders.

Though after fulfilment of concessionaire obligations after the project of " 4 Laning of the Patiala -SangrurBathinda section of NH-64 in the state of Punjab to IVRCL Patiala Bathinda Toll ways limited" (NHAI) was awarded, the concessionaire still faced a major regulatory obstacle apart from being provided with $80 \%$ of ROW within 180 days and $100 \%$ of ROW 90 days thereafter the date of execution concession agreement, provide forest clearance by MoEF within scheduled timelines, approval of ROB up to GAD level with in time lines was that a ban was imposed on mining by Punjab State Government for extraction of stone aggregates after the submission of bid and the authorities couldn't provide the concessionaire for arranging dedicated stone quarry.

These factors finally resulted in the non-submission of PBG and delay in Financial Closure, PWD, Punjab encashed EMD of Rs. $15.86 \mathrm{Cr}$.

\section{IMPEDIMENTS TO GROWTH OF ROAD INFRASTRUCTURE IN INDIA}

The shortcomings of the road construction industry make great difficulties that it should overcome to convey the ideal road infrastructure development program. Upon qualitative analysis of these case studies, the reasons for terminations were clustered in three broad categories - Financial Impediments, Legal and Operational Impediments

\subsection{Financial Impediments}

"Earlier there was no major demand from the financial system to fund road infrastructure investment as it was low and financed largely by budgetary allocations of public sector enterprises engaged in road infrastructure. Road infrastructure spending picked up substantially with an important role played by the private sector and greater recourse to the financial system. The financial system was able to respond to the rapidly rising demand for credit by road infrastructure companies largely because banks stepped up lending. As a result, it is estimated that banks were able to provide about half the debt finance needs of infrastructure investment. This rapid growth in bank credit to infrastructure has resulted in a greater concentration of risks in banks, due to ALM mismatch and reaching exposure ceilings" (Planning Commision Government of India).

"The total credit advances to road sector by 2012-2013 were INR 127,430 crores, which expanded to INR 180,277 crores as of September 2017-18. The share of NonPerforming Assets (NPAs) out of aggregate advances in the road sector increased from 1.9 percent of the credit funds in 2012-13, to 20.3 percent in September 2017-18" (Economic Survey 2017- 2018, 2018).

While banks, up until now, have assumed a vital part in providing finance to road infrastructure projects and supporting economic development, bank financing of road infrastructure in India is probably going to be on decline because of the developing pattern in stressed assets from this sector in their financial reports.

"The Ministry of Road Transport and Highways and National Highway Authority of India (NHAI) have been checking the stalled down projects. Wherever physical completion is established, one-time fund infusion by NHAI is being done to resuscitate slowed down ventures" (Indian Road Construction Industry Capacity Issues, Constraints and Recommendations, 2008).

The target of the program is to accomplish an ideal asset designation for an all-encompassing expressway improvement activity and beat the difficulties in financing road infrastructure. Spending deficiencies and obligation have decreased the capacity of government to subsidize by traditional strategies for distributing spending from the repetitive expenditure.

\subsection{Legal and Operational Impediments}

Non-budgetary constraints include long gestation periods and numerous legal and procedural issues other than arranging and execution issues. The issues identified with road infrastructure improvement go from those related to land acquisition to ecological clearances.

Land availability is a bigger issue than financial sanctions for road infrastructure projects. Multiple projects are yet to receive financial closure approvals. Interaction with road infrastructure developers like IVRCL indicates that delay in receiving financial closure is mainly due to non- availability of land because of

1. Non-availability of physical possession of land

2. Pending forest clearances, and

3. Utility shifting.

As of 2017-2018 a portion of projects under various phases of National Highway Development Program are deferred for the most part

Published By 
because of issues in the land acquisition, utility shifting, the poor execution of contractual workers, environmental and forest clearances, Road over Bridge (ROB) and Road under Bridge (RUB) issue with Railways.

"Land acquisition and environmental clearances continue to remain critical concerns for infrastructure developers. Both these issues have been prevalent since a long time and are the prime reasons for infrastructure projects to invariably getting delayed" (Economic Survey 2017- 2018, 2018).

\section{Assessmentof fcountry'sadherencetothe bestregaldatorypracticesat} the procurementstsageofPPP proiect| $\mid$ sale $1.100 \mid$

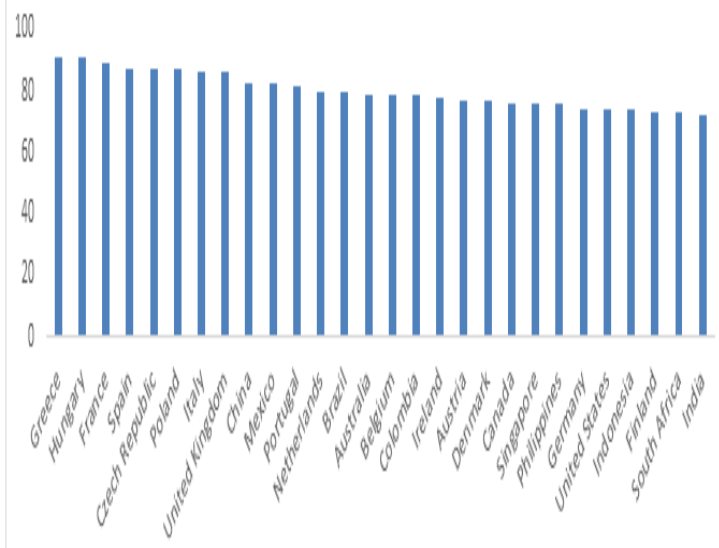

[Source: World Bank]

"Difficulty in acquiring land in rural and forest areas is cited as the major reason for delay of power projects. Due to lack of proper implementation of Acts and Rules relating to land acquisition as well as difficulty in approaching the concerned Department/Ministry/ Organisation at the right time, it has become difficult to acquire required land. In numerous cases, acquisition of land for the project by developers has posed a problem which in the last two three years has assumed a much larger proportion. There have been instances where developers in spite of having spent considerable funds and time on the development of the project, had to move to another site because of extreme resistance and protests by land owners and other local people. Further, given the population density and the type of land use in the country, there is more problem in land acquisition in India than probably elsewhere in the world. Thus, it is a big challenge for Government, both Central and State, to generate greater access of land to the people and corporate at large, including landless rural poor and foreign investors/ non-resident Indians, at the same time balancing the needs of one and all. Many projects got stuck due to delay in environmental clearances. Even more damaging is the uncertainty associated with the process. The Ministry of Environment has issued guidelines for clearances to projects, which at best serve as a starting point. Every project, however, needs to be cleared by the ministry. This increases the regulatory burden on the developmental process and the time that it is likely to take for the clearance to come through" (Planning Commision Government of India).

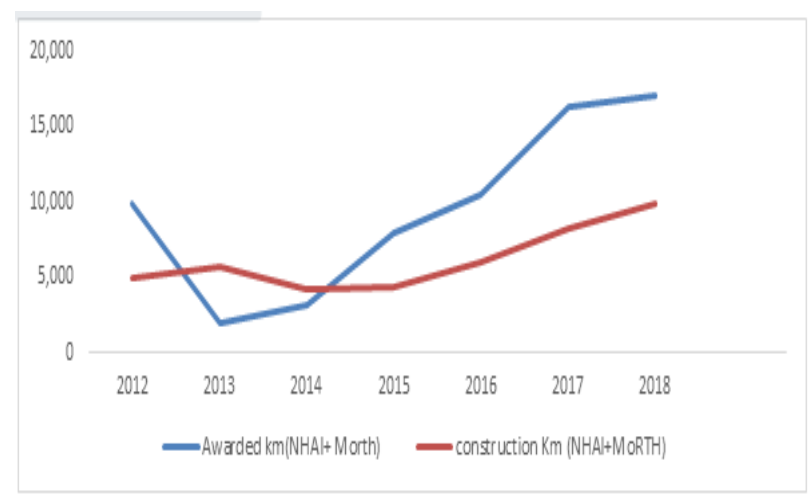

[Source: NHAI]

Postponements in pre-development exercises are a repeating issue across road development contracts. National highway ventures and other road projects take additional time than planned to hand over encumbrance free land to the contractors. Regularly, encumbrances, for example, the extent of land acquisition, utilities to be moved are not clearly distinguished and managed in an auspicious manner. The outcome is time and cost overruns and related disputes that perpetually wind up in prosecution. In past there were cases when Ministry of Railways have been extremely late with regards to ROB/RUB clearances, Defence Ministry had postponed exchange of defence land; a few clearances are pending for quite a while. Due to these financial, operational and regulatory hurdles private investors are reluctant towards investing in road infrastructure resulting in investment slowdown.

"Improving Dispute Resolution and Contract Management is extremely important from the point of view of profitability and one way to alleviate the situation is that land acquisition be done by the government prior to the project bidding stage and project commences only after land acquisition which enables in a reduction in time lag between bid for a project and the commencement of the construction and in turn reduce project costs and expedite implementation. Profitability in the road sector among all sectors is possibly the lowest due to non-transparency and poor governance, which often leads to compromise in quality and is one of the prime reasons for entering into litigation by contractors to make up for the losses or scant profits" (Indian Road Construction Industry Capacity Issues, Constraints and Recommendations, 2008).

So land acquisition issues should be addressed pro actively and have funding and financing models for road infrastructure which as there won't be any lack of private capital willing to venture in and put resources into gainful public infrastructure if the project subsidizing and financing models are robust

\section{BUSINESS MODEL RESULTS}

"It is evident from the case studies that Government and road infrastructure organizations need to cooperate to get risk sharing right in PPPs where they partner on complex road development ventures. Risk sharing course of action needs to strike the right balance, with the party best prepared 
to deal with the risk the one that goes out on a limb. There have been issues with some prominent projects where the private sector took on patronage risk when they were likely not the best party to oversee them and thusly endured a huge significant loss when the patronage levels were lower than forecast" (PWC, 2013). Enhancing risk allocation through proper procedures prompted the execution of Hybrid Annuity Model (HAM) to diminish the cost and danger of the PPP procedure to the bidders.

\subsection{Hybrid Annuity Model: (HAM)}

"Hybrid Annuity Model is a mix of two models BOTAnnuity (Build, Operate, and Transfer) and EPC (Engineering, Procurement, and Construction). HAM joins EPC and BOT-Annuity Models. In the interest of the Government, NHAI discharges 40 percent of the aggregate venture cost. The adjust 60 percent is arranged by the concessionaire. The concessionaire, for the most part, contributes not more than 20-25 percent of the undertaking cost, while the remaining is raised as a debt obligation. In BOT toll model, the private players do not demonstrate their eagerness to contribute, since they needed to completely arrange the whole funds, either through equity contribution or debt obligation. NHAI has taken great care to ensure that HAM is viewed as a deferred EPC model, rather than a modified BOT model. With $40 \%$ contribution coming from NHAI, project execution is significantly de risked. Also, since the annuity amount is linked via fixed percentages to project cost, the uncertainty related to revenues (traffic growth and tariff hike) has also been eliminated. Lastly, shorter duration of projects (15 years vs. 20-25 years for a BOT project) also ensures the developers can unlock and rotate capital sooner" (Economic Survey 2017- 2018, 2018).

NPA-baffled banks were hesitant to loan to these ventures. Since there was no remuneration structure, for example, the annuity, the concessionaire had to take the entire risk in low traffic projects. The pith of the HAM model emerged because of a prerequisite of a better monetary system where the risk would be spread amongst concessionaires and the Government.

\section{Projects in last three years}

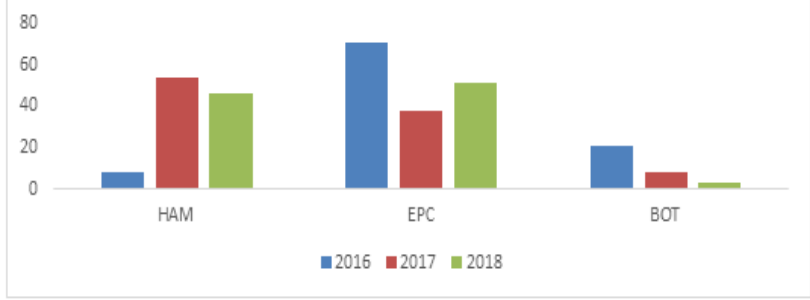

[Source: NHAI]

\subsection{Concessionaires and HAM Projects}

On the back of recent HAM project wins, order books of some of the developers have acquired high concentration of HAM projects- many of them are awaiting Financial Closure (FC). For players such as IRB, Ashoka, PNC and Dilip, more than $35 \%$ of their order books comprise of HAM projects awaiting FC (Motilal Oswal , 2018).

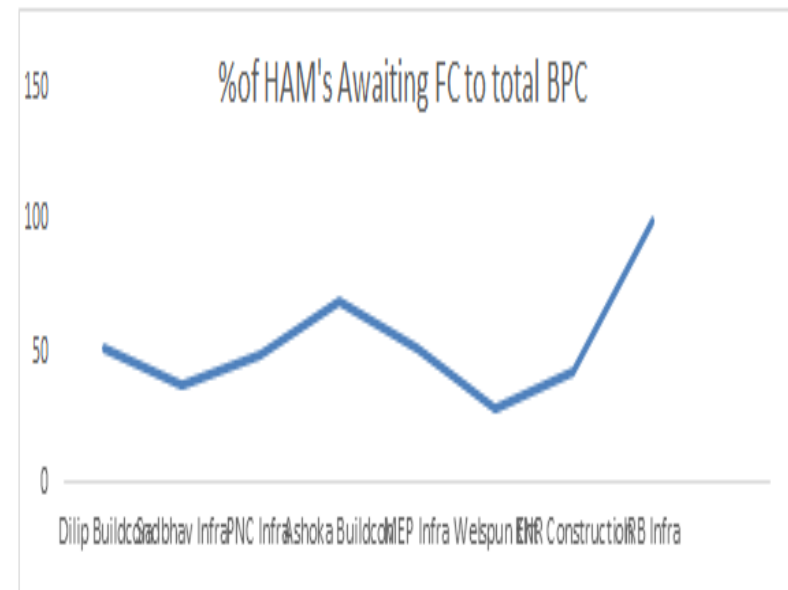

[Source: Motilal Oswal Infrastructure Sector Report]

\section{RECOMMENDATIONS}

5.1 Reusing the existing road projects to fund future projects

Asset reusing, otherwise called capital recycling is a broadly utilized business hone that comprises of arranging non-vital or failing to meet expectations advantages for open capital and reinvest it in different resources or undertakings that convey enhanced or extra advantages. Governments which own and operate highway assets and furthermore hold the obligation of conveying enhanced or new public services can adopt this training to address the issues of the populace. In asset reusing, the most well-known alternatives for divesting resources are temporary and partial proprietorship through a lease and concession agreement. This enables governments to keep up an immediate stake in the advantage as a noteworthy value investor. The second phase of divesting is to reinvest the capital from reusing existing assets into other valuable and significant projects. This method will advance putting resources into financially significant road infrastructure development projects that empower and advance efficiently and improve connectivity at a national level. This normally includes resources with client charges. Since it specifically creates cash flows, this venture will probably achieve the same or higher incentive as the assets divested. These assets enable governments to supplant old established sources of incomes from divested resources with new sources of revenues and give returns to the governments' operational spending plan and balance sheet. Asset reusing can likewise improve Greenfield PPPs by utilizing the capital proceeds to give assurances to investors as a backup credit extension. This enables the task to accomplish a higher venture review rating category than is conceivable from the undertaking on an independent premise. This can be especially helpful in developing markets like India where there can be perceived higher political dangers by investors. Government might want to recycle newly built road infrastructure foundation later. These will more probably happen if a portion of the returns is reinvested into a monetarily esteemed road infrastructure

Published By:

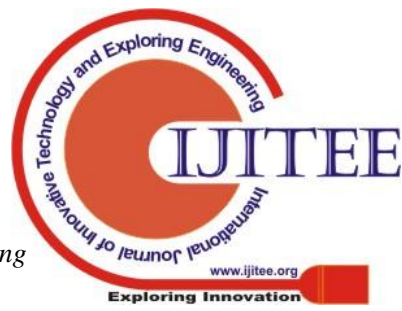


development that is appealing to the market once built and in operation.

"The NHAI declared plans to divest and adapt freely financed operational highways and other road undertakings to private companies utilizing a 30-year lease to operate and maintain the roadways, and for the private investors to gather incomes through user charges by means of toll stations in return for a forthright instalment" (World Economic Forum, Atkins Acuity, 2017).

This procedure needs to advance so that the assessed proceeds may fetch the administration the lump sum and can be utilized to put resources into building more highways and other road infrastructure ventures to meet the fast development and improve connectivity in India.

\subsection{Road Infrastructural Project Fund}

Creating a trusted support is a compelling method to reserve finances and permit the continued drawdown of money more than quite a while relying upon the new project's execution stage. This sort of reserve obviously shows responsibility, accountability, and straightforwardness to general society, and is a powerful method to set up trust and assemble bolster. The Road Infrastructure Trust Fund ought to have solid administration, autonomous reporting, and well-defined characterized key performance indicators approved by an independent audit to guarantee great execution.

"In 2007, the government of Canada propelled a Building Canada Plan, which intended to give "\$33 billion in steady, adaptable and predictable funding to regions, domains, and districts, enabling them to get ready for the more extended term and address their continuous infrastructure foundation needs". The Building Canada Fund works by "Investing in public infrastructure possessed by provincial, regional and municipal governments, and in specific cases, the private sector and non-benefit associations. Financing is dispensed to every area and domain in view of population. "The Building Canada Fund is a cost-shared commitment program with a "most extreme federal commitment to any single undertaking being 50 percent. "The Fund's point is to "construct a more grounded Canadian economy by putting resources into infrastructure projects that add to expanded trade, efficient movement of goods and people, and economic growth." One of the classes of investments that support financial growth and development includes the National Highway System and other road projects" (The Law Librarry of Congress, Global Research Center).

Similarly, by following the way Canada developed a infrastructural trust fund India needs to have one of its own for investing in road infrastructure for the well-being and better connectivity between the states.

\subsection{Raising Capital through Bond Market}

"Infrastructure companies in India have leveraged their balance sheets much above the optimum debt taking capacities on a given level of cash flows and assets. When Project Finance is used believing that Risk structuring and allocation can minimize increased risk of assets, it cannot essentially work in projects with flawed economics and politically sensitive macro environments as off take of cash flows become volatile. Therefore, this volatility in cash flows has resulted in higher Bankruptcy costs, which has resulted in a rise in higher risk premiums leading to higher cost of equity and debt. With the rise in Cost of Equity, it may not be feasible for the promoters of Infrastructure companies to raise further equity from the market. Thus most projects are debt driven. Supporting higher levels of debt requires more equity, with the amount varying with the level of project risk. Substantial resources were raised by infrastructure companies from IPO with the secondary market boom peaking in 2007-08 before drying up more recently" (India Brand Equity Foundation, 2018).

However short political cycles, short-term investment horizons, an absence of feasible financing structures, unseemly tactless risk evaluation frameworks and an absence of long-haul vision; leads to impediments in infrastructure growth and development in a country.

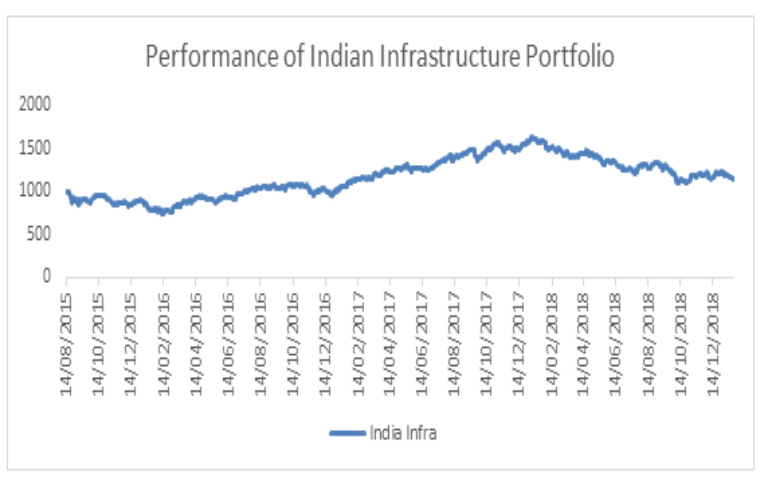

[Source: FactSet Terminal]

Exploring issuing securities with a 30-to-50-year tenor to support and underpin an extended term debt obligation market gives all around expanded budgetary framework, where bank and bond financing supplement each other, lessens financial delicacy and upgrades the effectiveness of capital allotment.

The advantages of a well-developed bond market with regards to road infrastructure development financing are broadening the subsidizing base, providing risk management apparatuses, reinforcing corporate administration and upgrading discipline by restricting the impact of borrowers on banks.

Further, with bank financing to the road infrastructure as of now at abnormal states, and the impending exposure norms that would restrict banks' capacity to lend, there is a pressing need to reallocate the financing exercises to the bond market in the overall interest of the financial framework.

\section{CONCLUSION}

Some of the recommendations listed here have been voiced by the construction industry stakeholders already where actions have been initiated by the concerned agencies. Infrastructure advancement assumes a crucial part in the improvement of the economy of the nation it likewise increases the competitive advantage. A fundamental basis for any nation lies on its financial market. Without the development of financial market investment in infrastructure

Published By:

Blue Eyes Intelligence Engineering

\& Sciences Publication 
is hard to accomplish the targeted growth and development. It is currently, for the most part, acknowledged that road infrastructure ventures require long-haul financing.

This paper features the issues faced by road infrastructure organizations in finishing the projects within time schedules without having the clear majority of the cost overrun, better utilization of off-budget plan, promote low-risk financial innovations and secure long-haul private investment in road infrastructure foundation. Current subsidizing levels miss the mark regarding the future investment expectations, and without bigger government spending portions, the current public position alone won't be adequate to meet the demand. To successfully draw in the private sector and have steady infrastructure advancement in India, the policymakers need to build up a fitting legitimate and administrative system, straightforward procedures and a provision of impetuses. Current funding levels fall short of the future investment expectations, and without larger government budget allocations, the existing public provision alone will not be enough to meet the demand. To effectively engage the private sector and have a stable infrastructure development in the India, the policymakers have developed an appropriate legal and regulatory framework, a suitable risksharing mechanism of Hybrid Annuity Model (HAM) Furthermore, Administration currently needs to set up a more complex structure with a specific end goal to diversify the traditional sources of financing as recommended Road Infrastructural trust Fund initiative needs to be created and used on conditions on the need premise. Authority may screen the fund utilization in the project. Component to assess the use of the reserve must be created. To manage all these new issues of recent time, the policymakers should think about a wide cluster of measures on a policy and the administrative level. Consequently, the management of road infrastructure development ventures is pivotal at this point. The accomplishment of these activities will now rely on the capacity of the government to generate a supply of PPP projects in an environment of policy assurance.

\section{WORKS CITED}

1. (N.d.). Retrieved from nhai: www.nhai.org

2. (2018). Economic survey 2017-2018. Government of india.

3. Haryana government. (n.d.). Retrieved from www.haryana.gov.in

4. India brand equity foundation. (2018). The indian infrastructure sector: investments, growth and prospects.

5. (2008). Indian road construction industry capacity issues, constraints and recommendations. The international bank for reconstruction and develoopment/ the world bank.

6. Motilal oswal . (2018). Infrastructure sector report. Motilal oswal

7. Planning commision government of india. (n.d.). Retrieved from http://planningcommission.nic.in/reports

8. Pwc. (2013). Securing investment in australia's future: infrastructure funding and financing. Business council of australia.

9. Srivastava, p. (2013). Infrastructure financing challenges of restructuring.

10. The law librarry of congress, global research center. National funding of road infrastrcture.

11. World economic forum, atkins acuity. (2017). Recycling our infrastructure for future generations. World economic forum

\section{LITERATURE SURVEY}

\begin{tabular}{|c|c|}
\hline S.no & Reviewed Paper \\
\hline 1. & $\begin{array}{l}\text { Noel, M., \& Brzeski, W. J. (2004). Mobilizing private finance for local infrastructure in } \\
\text { Europe and Central Asia: an alternative public private partnership framework. The World } \\
\text { Bank. }\end{array}$ \\
\hline 2. & $\begin{array}{l}\text { Atkinson, R. D., Shultz, M., Carmody, D. F., Crowe, J. C., Florian, M., Grote, B., ... \& } \\
\text { Moore, A. NATIONAL SURFACE TRANSPORTATION INFRASTRUCTURE } \\
\text { FINANCING COMMISSION. }\end{array}$ \\
\hline 3. & $\begin{array}{l}\text { Munnell, A. H. (1992). Policy watch: infrastructure investment and economic } \\
\text { growth. Journal of economic perspectives, 6(4), 189-198. }\end{array}$ \\
\hline 4. & $\begin{array}{l}\text { Henisz, W. J. (2002). The institutional environment for infrastructure investment. Industrial } \\
\text { and corporate change, 11(2), 355-389. }\end{array}$ \\
\hline 5. & $\begin{array}{l}\text { Button, K. (1998). Infrastructure investment, endogenous growth and economic } \\
\text { convergence. The annals of regional science, 32(1), 145-162. }\end{array}$ \\
\hline 6. & $\begin{array}{l}\text { Garvin, M. J., \& Cheah, C. Y. (2004). Valuation techniques for infrastructure investment } \\
\text { decisions. Construction Management and Economics, 22(4), 373-383. }\end{array}$ \\
\hline 7. & $\begin{array}{l}\text { Short, J., \& Kopp, A. (2005). Transport infrastructure: Investment and planning. Policy and } \\
\text { research aspects. Transport policy, 12(4), 360-367. }\end{array}$ \\
\hline
\end{tabular}




\begin{tabular}{|c|c|}
\hline 8. & $\begin{array}{l}\text { Castells, A., \& Solé-Ollé, A. (2005). The regional allocation of infrastructure investment: } \\
\text { The role of equity, efficiency and political factors. European Economic Review, 49(5), 1165- } \\
1205 .\end{array}$ \\
\hline 9. & $\begin{array}{l}\text { Ramamurti, R., \& Doh, J. P. (2004). Rethinking foreign infrastructure investment in } \\
\text { developing countries. Journal of World Business, 39(2), 151-167. }\end{array}$ \\
\hline 10. & $\begin{array}{l}\text { Perkins, P., Fedderke, J., \& Luiz, J. (2005). An analysis of economic infrastructure } \\
\text { investment in South Africa. South African Journal of Economics, 73(2), 211-228. }\end{array}$ \\
\hline 11. & $\begin{array}{l}\text { Wells, L. T., \& Gleason, E. S. (1995). Is foreign infrastructure investment still risky?. Long } \\
\text { Range Planning, } 6(28), 130 .\end{array}$ \\
\hline 12. & $\begin{array}{l}\text { Globerman, S., \& Shapiro, D. (2002). Global foreign direct investment flows: The role of } \\
\text { governance infrastructure. World development, 30(11), 1899-1919. }\end{array}$ \\
\hline 13. & $\begin{array}{l}\text { Aschauer, D. A. (1993). Genuine economic returns to infrastructure investment. Policy } \\
\text { Studies Journal, 21(2), 380-390. }\end{array}$ \\
\hline 14. & $\begin{array}{l}\text { Brown, C. (2005). Financing transport infrastructure: for whom the road tolls. Australian } \\
\text { Economic Review, 38(4), 431-438. }\end{array}$ \\
\hline 15. & $\begin{array}{l}\text { Nijkamp, P., \& Rienstra, S. A. (1995). Private sector involvement in financing and operating } \\
\text { transport infrastructure. The Annals of Regional Science, 29(2), 221-235. }\end{array}$ \\
\hline 16. & $\begin{array}{l}\text { Debande, O. (2002). Private financing of transport infrastructure: an assessment of the UK } \\
\text { experience. Journal of Transport Economics and Policy (JTEP), 36(3), 355-387. }\end{array}$ \\
\hline 17. & $\begin{array}{l}\text { Fay, M. (1999). Financing the future: infrastructure needs in Latin America, 2000-05. The } \\
\text { World Bank. }\end{array}$ \\
\hline 18. & $\begin{array}{l}\text { Odeck, J., \& Bråthen, S. (2002). Toll financing in Norway: The success, the failures and } \\
\text { perspectives for the future. Transport Policy, 9(3), 253-260. }\end{array}$ \\
\hline 19. & $\begin{array}{l}\text { Postigo, A. (2008). Financing road infrastructure in China and India: current trends and } \\
\text { future options. Journal of Asian Public Policy, } 1(1), 71-89 \text {. }\end{array}$ \\
\hline 20. & $\begin{array}{l}\text { Johansson, B., \& Mattsson, L. G. (Eds.). (2012). Road pricing: theory, empirical assessment } \\
\text { and policy. Springer Science \& Business Media. }\end{array}$ \\
\hline 21. & $\begin{array}{l}\text { Bousquet, F., \& Fayard, A. (1999). Road infrastructure concession practice in Europe. The } \\
\text { World Bank. }\end{array}$ \\
\hline 22. & $\begin{array}{l}\text { Crafts, N. (2009). Transport infrastructure investment: implications for growth and } \\
\text { productivity. Oxford Review of Economic Policy, 25(3), 327-343. }\end{array}$ \\
\hline 23. & $\begin{array}{l}\text { Banerjee, A., Duflo, E., \& Qian, N. (2012). On the road: Access to transportation } \\
\text { infrastructure and economic growth in China (No. w17897). National Bureau of Economic } \\
\text { Research. }\end{array}$ \\
\hline 24. & $\begin{array}{l}\text { Fay, M., \& Yepes, T. (2003). Investing in Infrastructure: What is Needed from } 2000 \text { to } \\
\text { 2010?. The World Bank. }\end{array}$ \\
\hline 25. & $\begin{array}{l}\text { Sahoo, P., \& Dash, R. K. (2009). Infrastructure development and economic growth in } \\
\text { India. Journal of the Asia Pacific economy, 14(4), 351-365. }\end{array}$ \\
\hline
\end{tabular}




\begin{tabular}{|c|c|}
\hline 26. & $\begin{array}{l}\text { Sahoo, P., Dash, R. K., \& Nataraj, G. (2010). Infrastructure development and economic } \\
\text { growth in China. Institute of Developing Economies Discussion Paper, } 261 .\end{array}$ \\
\hline 27. & $\begin{array}{l}\text { Bellier, M., \& Zhou, Y. M. (2003). Private participation in infrastructure in China: Issues } \\
\text { and recommendations for the road, water, and power sectors. The World Bank. }\end{array}$ \\
\hline 28. & $\begin{array}{l}\text { Pradhan, R. P., \& Bagchi, T. P. (2013). Effect of transportation infrastructure on economic } \\
\text { growth in India: the VECM approach. Research in Transportation Economics, 38(1), 139- } \\
148 .\end{array}$ \\
\hline 29. & $\begin{array}{l}\text { Thomas, A. V., Kalidindi, S. N., \& Ananthanarayanan, K. A. B. T. (2003). Risk perception } \\
\text { analysis of BOT road project participants in India. Construction Management and } \\
\text { Economics, 21(4), 393-407. }\end{array}$ \\
\hline 30. & $\begin{array}{l}\text { Lakshmanan, L. (2008). Public-private partnership in Indian infrastructure development: } \\
\text { issues and options. Reserve Bank of India Occasional Papers, 29(1), 37-41. }\end{array}$ \\
\hline
\end{tabular}

